\title{
Structural characteristic of vanadium(V) oxide/sulfur composite cathode for magnesium battery applications
}

\author{
E. SHEHA ${ }^{1, *}$, E.M. KAMAR ${ }^{2}$ \\ ${ }^{1}$ Physics Department, Faculty of Science, Benha University, Benha, Egypt \\ ${ }^{2}$ Chemistry Department, Faculty of Science, Benha University, Benha, Egypt
}

\begin{abstract}
Magnesium batteries are regarded as promising candidates for energy storage devices owing to their high volumetric capacity. The practical application is hindered, however, by strong electrostatic interactions between $\mathrm{Mg}^{2+}$ and the host lattice and due to the formation of a passivation layer between anode and electrolyte. $\mathrm{V}_{2} \mathrm{O}_{5}$ is a typical intercalation compound with a layered crystal structure $\left(\begin{array}{lll}0 & 0 & 1\end{array}\right)$ interlayer spacing $\sim 11.53 \AA$ ), which can act as a good host for the reversible insertion and extraction of multivalent cations. Herein, we have presented an investigation of the effects of $\mathrm{S}$ injection on the structure, electrochemical performance and $\mathrm{Mg}^{2+}$ diffusion in $\mathrm{V}_{2} \mathrm{O}_{5}$ cathode materials for $\mathrm{Mg}$-ion batteries. The $\mathrm{V}_{2} \mathrm{O}_{5} / \mathrm{S}$ composite structure was investigated using $\mathrm{X}$-ray diffraction, field-emission scanning electron microscope and energy dispersive X-ray spectroscopy. The integrated electrode exhibits an improvement in the electrical and electrochemical properties compared to the $\mathrm{V}_{2} \mathrm{O}_{5}$ electrode. The as-prepared $\mathrm{V}_{2} \mathrm{O}_{5} / \mathrm{S}$ composite has an initial discharge capacity of $310 \mathrm{mAh} \cdot \mathrm{g}^{-1}$ compared to $160 \mathrm{mAh} \cdot \mathrm{g}^{-1}$ for the $\mathrm{V}_{2} \mathrm{O}_{5}$ electrode. The $\mathrm{V}_{2} \mathrm{O}_{5} / \mathrm{S}$ composite is a promising cathode material for magnesium-ion battery applications.
\end{abstract}

Keywords: $\mathrm{V}_{2} \mathrm{O}_{5}$; SEM, conductivity; magnesium batteries

\section{Introduction}

Lithium-based batteries power everything from phones to electric cars, and while the lithium metal does the job for now, there are plenty of rooms for improvement in terms of efficiency and price. Magnesium, on the other hand, has a higher energy density than lithium and is far more abundant in the natural world, which might deliver batteries with higher density of energy storage and transformative advances in safety, cost and performance compared to lithium-ion ( $\mathrm{Li}$-ion). $\mathrm{Mg}$ is the eighth most earthabundant metal on the earth's crust [1]. However, advancement of magnesium rechargeable batteries has been hampered by limited choice of electrolyte and cathode materials in view of facile passivation of $\mathrm{Mg}$ surface and sluggish solid-state diffusion of highly polar divalent cation in lattices [2-4]. The prototype magnesium rechargeable batteries were developed in 2000, utilizing solutions comprising $\mathrm{Mg}$ organo-halo-aluminate complexes and ether solvents (THF, glymes) that are convenient

*E-mail: islam.shihah@fsc.bu.edu.eg with both magnesium metal anodes and $\mathrm{Mo}_{6} \mathrm{~S}_{8}$ cathodes [5]. Different types of Chevrel phase $\left(\mathrm{Mg}_{\mathrm{x}} \mathrm{Mo}_{6} \mathrm{~T}_{8}, \mathrm{~T}=\mathrm{S}, \mathrm{Se}\right)$ cathodes for rechargeable $\mathrm{Mg}$ batteries have been thoroughly explored [6, 7]. Various candidates have been suggested in recent years for magnesium battery cathode materials with capacity and redox voltage higher than those of Chevrel phases $\left(120 \mathrm{mAh} \cdot \mathrm{g}^{-1} ; 1.1 \mathrm{~V}\right.$ vs. $\mathrm{Mg}$ ) $[8,9]$. Layered transition metal oxides are favorable because they may possess the structural flexibility [10] needed to follow the expected severe structural deformations upon insertion of bivalent ions such as $\mathrm{Mg}^{2+}$ of high charge density. Orthorhombic $\mathrm{V}_{2} \mathrm{O}_{5}$ is one such material that offers exciting prospects of being a reversible intercalating cathode for Mg batteries $[5,11,12]$. The theoretical energy density of a cathode based on $\mathrm{Mg}$ intercalation into $\mathrm{V}_{2} \mathrm{O}_{5}$ is $\sim 660 \mathrm{Wh} / \mathrm{kg}$ [13], which approaches the practical energy densities of current commercial Li-ion chemistries $(\sim 700 \mathrm{Wh} / \mathrm{kg}$ for $\mathrm{LiCoO}_{2}$ ) [14]. Such a layered framework host is of great interest in $\mathrm{Mg}$ intercalation mostly owing to its ability to adapt to the geometry of the intercalated guest species by adjusting the interlayer 
separation. Several studies specified the possibility that this compound may insert $\mathrm{Mg}$ ion in conventional nonaqueous $\mathrm{Mg}$ salt solutions with some degree of reversibility. However, none of these studies explains performance that would make it possible to consider $\mathrm{V}_{2} \mathrm{O}_{5}$ as a cathode material for rechargeable $\mathrm{Mg}$ batteries. Too low capacity and slow rates of $\mathrm{Mg}$-ion insertion into this host material could be referred to strong Coulombic interactions of the bivalent cations within the host lattice. Sulfur is one of the most promising candidates for conversion cathodes because of its high theoretical capacity $\left(1672 \mathrm{mAh} \cdot \mathrm{g}^{-1}\right)$, volumetric capacity $\left(3459 \mathrm{mAh} \cdot \mathrm{cm}^{-3}\right)$ as well as its reserve abundance [15]. $\mathrm{V}_{2} \mathrm{O}_{5}$ with added sulfur has been studied as a cathode material for lithium batteries because of the unique charge-discharge properties of this material [16]. However, the addition of sulfur requires a highly precise and well-controlled synthesis [16]. Magnesium batteries could be safer and more efficient than the lithium ones. The major difference as compared to lithium is that $\mathrm{Mg}$ metal does not form dendrites during deposition, which makes it potentially longer lasting and substantially safer than a Li metal anode $[17,18]$.

In the work reported herein, an attempt was made to study the impact of S doping on the structural, morphological, electrical and electrochemical properties of vanadium pentoxide via sonochemical method. The goal was to develop a unique cathode material allowing the insertion/extraction of magnesium ions and exhibiting high capacity. The manipulation of the interlayer spacing and amorphization of $\mathrm{V}_{2} \mathrm{O}_{5}$ can increase $\mathrm{Mg}^{2+}$ accommodation sites and offer a cathode with high initial capacity. $\mathrm{V}_{2} \mathrm{O}_{5} / \mathrm{S}$ exhibited good properties in hosting magnesium ions and its electrochemical performance.

\section{Experimental}

Nanosized $\mathrm{V}_{2} \mathrm{O}_{5} / \mathrm{S}$ composite was prepared using modified sonochemical technique. Vanadium pentoxide (99.6\% Alfa Aesar) and sulfur (99.5\% Alfa Aesar) were mixed at a molar ratio of 90:10. The powder mixture was grinded for 30 minutes using an agate mortar. After that, the mixture was uniformly dispersed in $50 \mathrm{~mL}$ of deionized water by ultrasonication for $3 \mathrm{~h}$ at room temperature. Finally, the mixture was dried in an oven at $90{ }^{\circ} \mathrm{C}$ for $24 \mathrm{~h}$ in air. The X-ray diffraction (XRD) patterns of the prepared samples were obtained using a PANanalytical X-ray diffraction system model X'Pert PRO with monochromator, $\mathrm{Cu}$ radiation $(\lambda=1.542 \AA)$ at $50 \mathrm{kV}, 40 \mathrm{~mA}$ and scanning speed of $0.02 \%$. The morphology was investigated by scanning electron microscope (FE-SEM, Quanta 250 FEG) with an energy-dispersive Xray (EDX) unit attached. Impedance spectroscopy measurements were performed on the CHI604E electrochemical workstation in the frequency ranging from $1 \mathrm{~Hz}$ to $1 \mathrm{MHz}$ at different temperatures. The magnesium rechargeable batteries were assembled into 2032-type coin cells with magnesium foil as the anode, and filter paper as the separator. The $\mathrm{Mg}$ foil was mechanically polished to remove the oxide layer. The active material was prepared by mixing the mixture of as-prepared $\mathrm{V}_{2} \mathrm{O}_{5}$ or $\mathrm{V}_{2} \mathrm{O}_{5} / \mathrm{S}$ powder, PVDF binder and super carbon $\mathrm{P}$ at a weight ratio of 75:15:10 with a few drops of N-methyl-pyrrolidone. The slurry was coated with a $\mathrm{Cu}$ foil and dried for two hours at $100{ }^{\circ} \mathrm{C}$. Electrolyte solution was synthesized via dissolving $5 \mathrm{M} \mathrm{MgNO}_{3} \cdot 6 \mathrm{H}_{2} \mathrm{O}$ in 2,2-dimethoxypropane MHMD [19]. The charge/discharge profiles were measured on a Neware battery tester CT3008. Cyclic voltammograms of MHMD electrolyte solution were performed on the CHI604E Electrochemical Workstation using a two-electrode coin cell, where the working electrode was $\mathrm{V}_{2} \mathrm{O}_{5}$ or $\mathrm{V}_{2} \mathrm{O}_{5} / \mathrm{S}$ composite while the counter and reference electrodes are $\mathrm{Mg}$ metal. $\mathrm{CV}$ were performed also with a three electrode cell using $\mathrm{Al}$ as a working electrode (WE) and $\mathrm{Mg}$ foil as counter and reference electrodes. The measurements were carried out at $0.5 \mathrm{mV} \cdot \mathrm{s}^{-1}$ and ambient conditions.

\section{Results and discussion}

Fig. 1 shows the XRD patterns of pure $\mathrm{V}_{2} \mathrm{O}_{5}$, $\mathrm{S}$ and $\mathrm{V}_{2} \mathrm{O}_{5} / \mathrm{S}$ composite. The characteristic XRD peaks of pure $\mathrm{V}_{2} \mathrm{O}_{5}$ at $2 \theta=15.53^{\circ}, 20.40^{\circ}, 21.84^{\circ}$, $26.27^{\circ}, 31.11^{\circ}, 32.48^{\circ}, 34.41^{\circ}, 41.39^{\circ}, 45.57^{\circ}$, $47.43^{\circ}$ and $51.29^{\circ}$, which correspond to the $(200)$, 
(0 0 1 1), (1 $\left.\begin{array}{lll}1 & 0 & 1\end{array}\right),\left(\begin{array}{lll}1 & 1 & 0\end{array}\right),\left(\begin{array}{lll}3 & 0 & 1\end{array}\right),\left(\begin{array}{lll}0 & 1 & 1\end{array}\right),\left(\begin{array}{lll}3 & 1 & 0\end{array}\right)$, $\left(\begin{array}{lll}0 & 0 & 2\end{array}\right),\left(\begin{array}{lll}4 & 1 & 1\end{array}\right),\left(\begin{array}{lll}6 & 0 & 0\end{array}\right)$ and $\left(\begin{array}{lll}0 & 2 & 0\end{array}\right)$ lattice planes of the $\mathrm{V}_{2} \mathrm{O}_{5}$ orthorhombic structure [20] (JCPDS Card No. 41-1426), were detected in both pure $\mathrm{V}_{2} \mathrm{O}_{5}$ and $\mathrm{V}_{2} \mathrm{O}_{5}-\mathrm{S}$ composite. The identified diffraction peaks can be indexed to the orthorhombic $\mathrm{V}_{2} \mathrm{O}_{5}$ phase (space group: Pmmn (No. 59); $\mathrm{a}=11.516 \AA, \mathrm{b}=3.565 \AA, \mathrm{c}=4.372 \AA$. According to Londero et al. [21], the structure of $\mathrm{V}_{2} \mathrm{O}_{5}$ has an orthorhombic layered structure, which forms intercalation layers. As a result, it offers a possibility of reversible intercalation of different atoms, molecules or ions. The interlayer separation of $\mathrm{V}_{2} \mathrm{O}_{5}$ changes depending on the size and shape of intercalated particles [22]. Also, it can be seen that the crystal structure of pure $\mathrm{V}_{2} \mathrm{O}_{5}$ has the strongest intensity of the $\left(\begin{array}{lll}0 & 0 & 1\end{array}\right)$ plane at $2 \theta=20.40^{\circ}$, with a d-spacing of $4.34 \AA$, while $\mathrm{V}_{2} \mathrm{O}_{5} / \mathrm{S}$ composite has the same peak with a dspacing of $4.35 \AA$. It was confirmed that small ratio of sulfur expanded the interlayer spacing of $\mathrm{V}_{2} \mathrm{O}_{5}$ in $\left(\begin{array}{lll}0 & 0 & 1\end{array}\right)$ direction, shielded the powerful polarization effect of divalent $\mathrm{Mg}^{2+}$ ions and could facilitate the intercalation process of $\mathrm{Mg}^{2+}$ ions [23]. The sulfur insertion succeeded in expanded interplanar distance of $\left(\begin{array}{lll}0 & 0 & 1\end{array}\right)$ plane from $4.34 \AA$ to $4.35 \AA$. This unique architecture can provide abundant active sites for $\mathrm{Mg}^{+2}$ ion insertion/extraction and conversion. Furthermore, compared to the relative intensities of the (lllll $\left.\begin{array}{lll}0 & 1\end{array}\right)$ and $\left(\begin{array}{lll}1 & 1 & 0\end{array}\right)$ diffraction peaks in Fig. 1, it is clear that the as-prepared $\mathrm{V}_{2} \mathrm{O}_{5} / \mathrm{S}$ composite demonstrates higher relative intensity of $\left(\begin{array}{lll}1 & 1 & 0\end{array}\right)$ plane. This peak intensity shift can be attributed to the enlarged interlayer distance value. As well, ( $\left(\begin{array}{lll}1 & 1 & 0\end{array}\right)$ crystal planes of $\mathrm{V}_{2} \mathrm{O}_{5} / \mathrm{S}$ composite provide channels for facile $\mathrm{Mg}^{2+}$ ion insertion and extraction [24]. The morphologies of the pure $\mathrm{V}_{2} \mathrm{O}_{5}$ and as-prepared $\mathrm{V}_{2} \mathrm{O}_{5} / \mathrm{S}$ composite were studied using field-emission scanning electron microscope (SEM) as displayed in Fig. 2. The low and high magnification FE-SEM images of the pure $\mathrm{V}_{2} \mathrm{O}_{5}$ (Fig. 2a and Fig. 2b) show uniform rod-like structures with the width ranging between $60 \mathrm{~nm}$ and $100 \mathrm{~nm}$.

These nanorods tend to assemble to form bundles in the same direction. The as prepared $\mathrm{V}_{2} \mathrm{O}_{5} / \mathrm{S}$ composite (Fig. 2c and Fig. 2d) exhibits similar

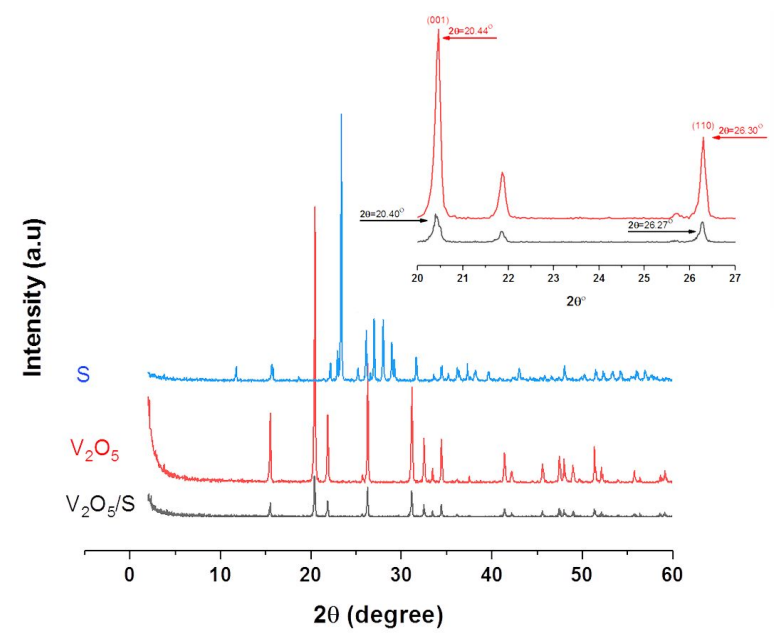

Fig. 1. XRD patterns of pure $\mathrm{V}_{2} \mathrm{O}_{5}, \mathrm{~V}_{2} \mathrm{O}_{5} / \mathrm{S}$ and sulfur element.

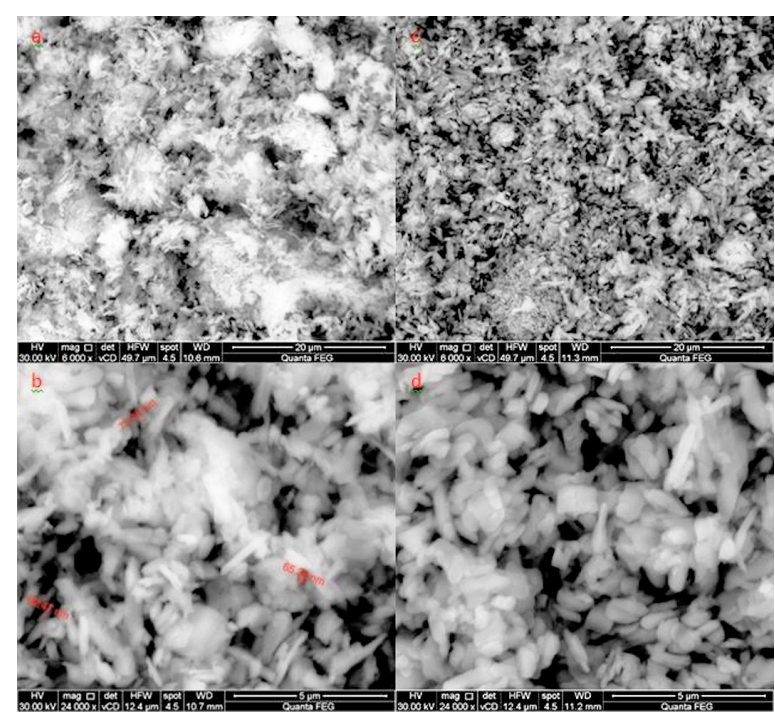

Fig. 2. FE-SEM images of pure $\mathrm{V}_{2} \mathrm{O}_{5}$ (a) and (b) and $\mathrm{V}_{2} \mathrm{O}_{5} / \mathrm{S}$ composite $(\mathrm{c})$ and $(\mathrm{d})$.

morphology of rod-like shapes. However, high magnification FE-SEM image of the $\mathrm{V}_{2} \mathrm{O}_{5} / \mathrm{S}$ composite reveals that decreased and more homogenously distributed aggregates appear. Fig. 3 shows EDS spectra of $\mathrm{V}_{2} \mathrm{O}_{5} / \mathrm{S}$ composite. The results confirm the presence of sulfur with $\mathrm{V}_{2} \mathrm{O}_{5}$ particles. The molar ratio of $\mathrm{V}: \mathrm{S}$ is 34.48:0.29 (in at.\%), in addition, the elemental mapping in Fig. 4, showing uniformity of the $\mathrm{V}, \mathrm{O}$, and $\mathrm{S}$ elements, indicates that the $\mathrm{V}_{2} \mathrm{O}_{5}$ nanoparticles and sulfur are homogeneously distributed in $\mathrm{V}_{2} \mathrm{O}_{5} / \mathrm{S}$ 
composite, which is consistent with the SEM images. Fig. 5a shows the relationship between the electrical conductivity and the reciprocal temperature of the $\mathrm{V}_{2} \mathrm{O}_{5}$ and $\mathrm{V}_{2} \mathrm{O}_{5} / \mathrm{S}$ electrodes at frequency $1 \mathrm{kHz}$. It is clear from the figure that the electrical conductivity increased after doping with sulfur element and can be attributed to the consecutive $\mathrm{O} / \mathrm{S}$ exchange reactions which led to formation of sulfur/vanadium oxide cluster anions $\mathrm{VO}_{3} \mathrm{~S}_{2}^{-}$and $\mathrm{VO}_{4} \mathrm{~S}_{1}^{-}$[25]. The existence of $\mathrm{VO}_{3} \mathrm{~S}_{2}^{-}$ and $\mathrm{VO}_{4} \mathrm{~S}_{1}^{-}$acts as a co-bridge which can facilitate the translational charge carrier motion, enhancing the ions diffusion and the electrical conductivity. The Arrhenius equation was used to calculate activation energy and the results showed that the activation energy decreased from $0.83 \mathrm{eV}$ to $0.39 \mathrm{eV}$ after doping with the sulfur element. The reduction in the activation energy confirms the role of sulfur in improving the mobility of ions and its effect in improving the electrochemical performance. Fig. $5 \mathrm{~b}$ illustrates the $\mathrm{Mg}$ plating/stripping behavior of the MHMD electrolyte. It is seen that the reduction process begins from $0.2 \mathrm{~V}$. In the subsequent oxidation step, the onset of the oxidation voltage is about $1.5 \mathrm{~V}$. The oxidation peak at about $1.75 \mathrm{~V}$ is attributed to the electrochemical dissolution of $\mathrm{Mg}$. The $\mathrm{CV}$ clearly shows that the as-synthesized electrolyte enables reversible $\mathrm{Mg}$ deposition/dissolution. Fig. 5c shows a CV of cell $1\left(\mathrm{Mg} /\right.$ electrolyte/ $\left./ \mathrm{V}_{2} \mathrm{O}_{5}\right)$ and cell 2 (Mg/electrolyte/ $/ \mathrm{V}_{2} \mathrm{O}_{5} / \mathrm{S}$ ) acquired between $-0.8 \mathrm{~V}$ and $2.2 \mathrm{~V}$ at a low scan rate of $1 \mathrm{mV} \cdot \mathrm{s}^{-1}$ and ambient condition.

For cell $1\left(\mathrm{~V}_{2} \mathrm{O}_{5}\right)$, the reduction current (magnesium insertion) with an onset potential of $0.6 \mathrm{~V}$ shows an increasing trend up to $-0.8 \mathrm{~V}$. This behavior can be attributed to the reduction of $\mathrm{V}^{5+}$ to $\mathrm{V}^{4+}$ forming $\mathrm{Mg}_{\mathrm{x}} \mathrm{V}_{2} \mathrm{O}_{5}$. In the subsequent anodic scan, a substantial oxidation current (magnesium extraction) with an onset potential of $0.8 \mathrm{~V}$ still increases linearly until $2 \mathrm{~V}$. This anodic current can be attributed to the phase transition of $\mathrm{Mg}_{\mathrm{x}} \mathrm{V}_{2} \mathrm{O}_{5}$ to $\mathrm{V}_{2} \mathrm{O}_{5}$ and extraction of $\mathrm{Mg}^{2+}$. For cell $2\left(\mathrm{~V}_{2} \mathrm{O}_{5} / \mathrm{S}\right)$, it can be seen a high reduction and oxidation current comparing to pure $\mathrm{V}_{2} \mathrm{O}_{5}$ electrode. This can be attributed to the redox of elemental sulfur to $\mathrm{Mg}$ polysulfides $\left(\mathrm{MgS}_{\mathrm{X}}\right): 2 \mathrm{Mg}^{2+}+\mathrm{S}_{8}+4 \mathrm{e}^{-} \leftrightarrow$

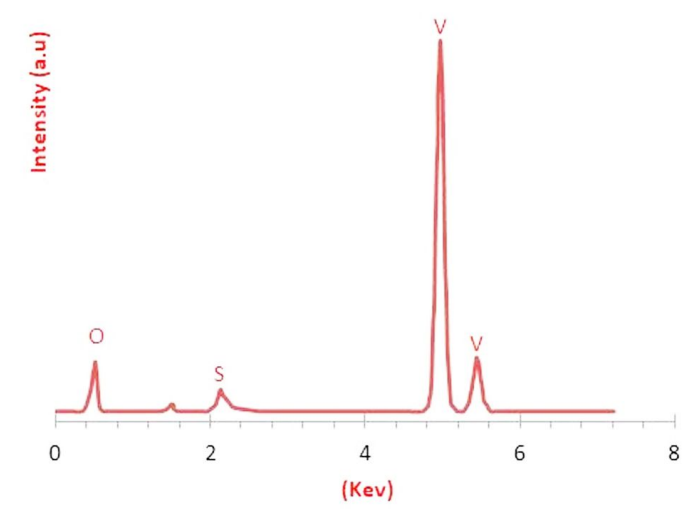

Fig. 3. EDS spectrum of $\mathrm{V}_{2} \mathrm{O}_{5} / \mathrm{S}$.

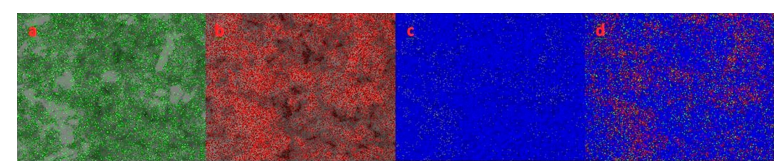

Fig. 4. EDS elemental mappings of $\mathrm{V}_{2} \mathrm{O}_{5} / \mathrm{S}$ composite. The elements of sulfur (a), oxygen (b), and vanadium (c), (d) V, O and S (d), respectively, are characterized.

$2 \mathrm{MgS}_{4}[26,27]$. Generally, doping $\mathrm{V}_{2} \mathrm{O}_{5}$ cathode with $\mathrm{S}$ might introduce more active sites accommodating $\mathrm{Mg}^{2+}$ comparing to pure $\mathrm{V}_{2} \mathrm{O}_{2}$ cathodes.

Fig. 6a displays the first and second charge and discharge curves of pure $\mathrm{V}_{2} \mathrm{O}_{5}$, and the $\mathrm{V}_{2} \mathrm{O}_{5} / \mathrm{S}$ electrodes. As shown in this figure, pure $\mathrm{V}_{2} \mathrm{O}_{5}$ exhibits a quasi-plateau located at $0.7 \mathrm{~V}$, while $\mathrm{V}_{2} \mathrm{O}_{5} / \mathrm{S}$ exhibits a quasi-plateau located at $0.4 \mathrm{~V}$ in the initial discharge curve. In case of the charge curves, $\mathrm{V}_{2} \mathrm{O}_{5} / \mathrm{S}$ electrode exhibits one plateau located at $1.75 \mathrm{~V}$ and continued up to $1.8 \mathrm{~V}$ (the cut off voltage), corresponding to reversible extraction of $\mathrm{Mg}^{2+}$. The initial charge potential plateau and the cut off voltage for $\mathrm{V}_{2} \mathrm{O}_{5} / \mathrm{S}$ electrode of $1.75 \mathrm{~V}$ and $1.85 \mathrm{~V}$, respectively, are much lower than for $\mathrm{V}_{2} \mathrm{O}_{5}$ electrode. Additionally, $\mathrm{V}_{2} \mathrm{O}_{5} / \mathrm{S}$ electrode delivered high initial charge and discharge capacities of $300 \mathrm{mAh} \cdot \mathrm{g}^{-1}$ which are higher than the values of $\mathrm{V}_{2} \mathrm{O}_{5}$ electrode of $100 \mathrm{mAh} \cdot \mathrm{g}^{-1}$ and $183 \mathrm{mAh} \cdot \mathrm{g}^{-1}$, respectively. The $2^{\text {nd }}$ discharge/charge capacities of $\mathrm{V}_{2} \mathrm{O}_{5}$ and $\mathrm{V}_{2} \mathrm{O}_{5} / \mathrm{S}$ electrodes are 80/20 $\mathrm{mAh} \cdot \mathrm{g}^{-1}$ and 120/190 $\mathrm{mAh} \cdot \mathrm{g}^{-1}$, respectively. Fig. $6 \mathrm{~b}$ presents the cycling performance of the pure $\mathrm{V}_{2} \mathrm{O}_{5}$, and $\mathrm{V}_{2} \mathrm{O}_{5} / \mathrm{S}$ electrodes. 


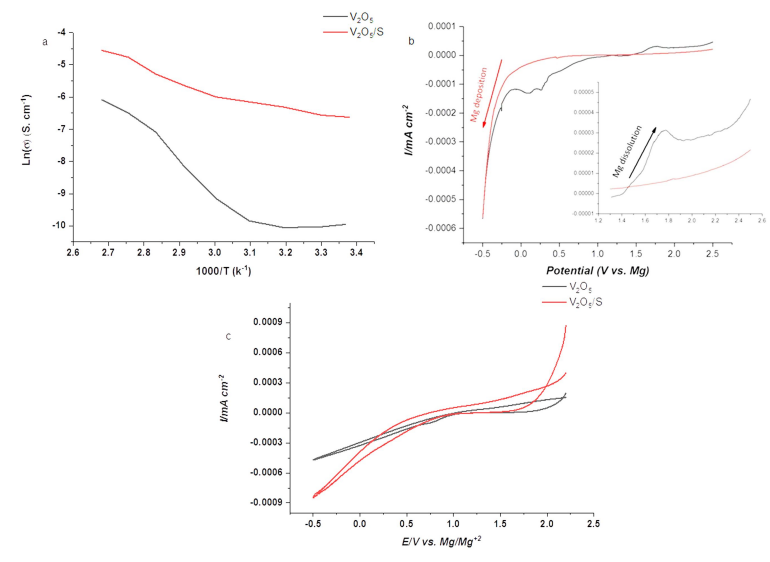

Fig. 5. (a) ionic conductivity versus reciprocal temperature of the $\mathrm{V}_{2} \mathrm{O}_{5}$ and $\mathrm{V}_{2} \mathrm{O}_{5}$ composite cathode; (b) CVs in MHMD electrolyte on $\mathrm{Al}$ electrodes at a scan rate of $0.5 \mathrm{mV} \cdot \mathrm{s}^{-1}$; (c) $\mathrm{CV}$ curves of $\mathrm{V}_{2} \mathrm{O}_{5}$ and $\mathrm{V}_{2} \mathrm{O}_{5} / \mathrm{S}$ composite cathode.

It can be seen that the reversible capacity suffers from fast fading after the first two cycles. The $\mathrm{V}_{2} \mathrm{O}_{5} / \mathrm{S}$ electrode, however, shows high capacity at the first two cycles comparing to pure $\mathrm{V}_{2} \mathrm{O}_{5}$ electrode. This can be attributed to the extra active surface area obtained due to introduction of sulfur.

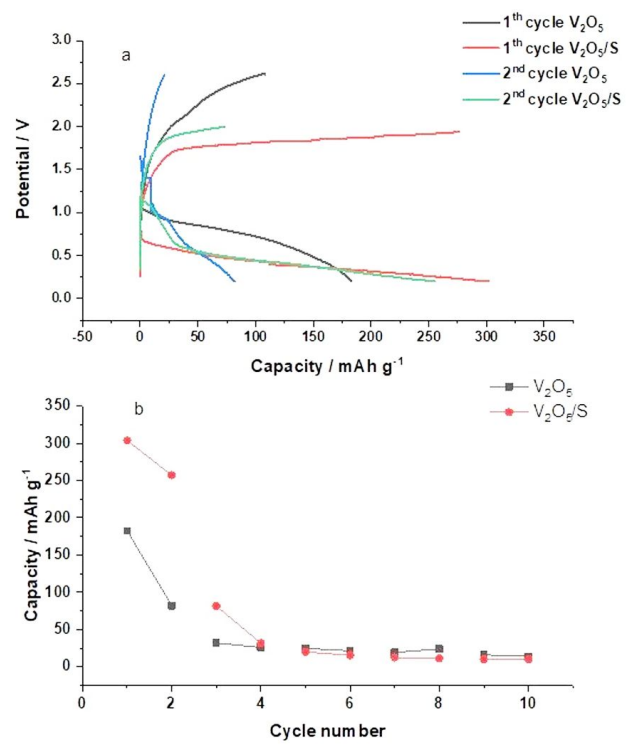

Fig. 6. (a) galvanostatic magnesiation/demagnesiation potential profiles of $\mathrm{Mg} / \mathrm{V}_{2} \mathrm{O}_{5}, \mathrm{Mg} /\left(\mathrm{V}_{2} \mathrm{O}_{5} / \mathrm{S}\right)$ coin cells; (b) cycling performances of $\mathrm{Mg} / \mathrm{V}_{2} \mathrm{O}_{5}, \mathrm{Mg} /\left(\mathrm{V}_{2} \mathrm{O}_{5} / \mathrm{S}\right)$ coin cells.
Fig. 7a shows the Nyquist plots of $\mathrm{Mg} / \mathrm{V}_{2} \mathrm{O}_{2}$ and $\mathrm{Mg} /\left(\mathrm{V}_{2} \mathrm{O}_{5} / \mathrm{S}\right)$ coin cells. The data were analyzed on the basis of the Randles equivalent circuit given in Fig. 7a. The semicircle in the high frequency region represents the charge transfer resistance at cathode-electrolyte interface $\mathrm{R}_{\mathrm{ct}}$ and the lower frequency inclined line represents Warburg impedance $\mathrm{W}_{\mathrm{s}}$ corresponding to the magnesium ion diffusion into the bulk of the electrode. The EIS data were fitted using the EIS spectrum analyzer software and the equivalent electrical circuit is shown in the inset of Fig. $7 \mathrm{a} . \mathrm{R}_{\Omega}$ corresponds to the ohmic resistance of the whole stack. CPE represents the double-layer capacitive effects. The values of the impedance parameters are listed in Table 1.
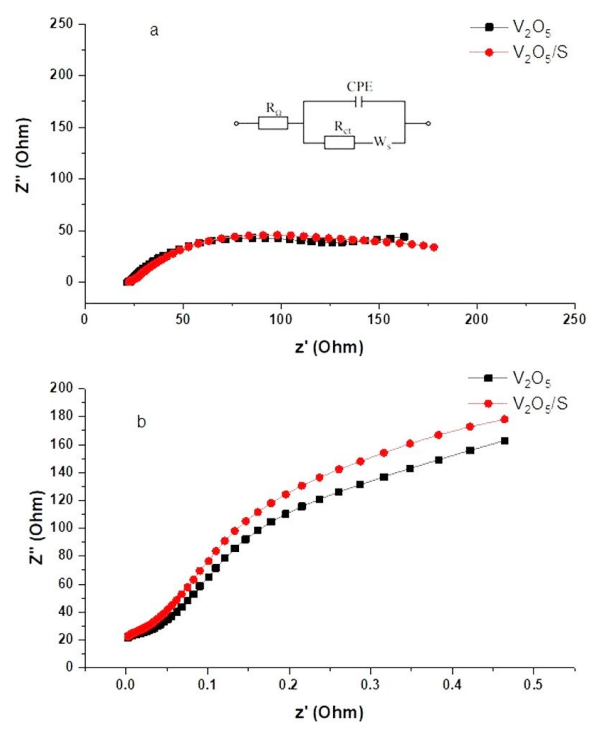

Fig. 7. (a) electrochemical impedance spectra (EIS) of the $\mathrm{V}_{2} \mathrm{O}_{5}$ and $\mathrm{V}_{2} \mathrm{O}_{5} / \mathrm{S}$ composite, (b) linear fitting of Warburg impedance of the $\mathrm{V}_{2} \mathrm{O}_{5}$ and $\mathrm{V}_{2} \mathrm{O}_{5} / \mathrm{S}$ composite.

The ohmic resistances are similar in the two cells $(\approx 23 \Omega)$. Meanwhile, the $\mathrm{V}_{2} \mathrm{O}_{5} / \mathrm{S}$ electrode exhibits a little larger $\mathrm{R}_{\mathrm{ct}}$ than the $\mathrm{V}_{2} \mathrm{O}_{5}$, suggesting the formation of solid electrolyte interphase (SEI) a bit thicker than in $\mathrm{V}_{2} \mathrm{O}_{5} / \mathrm{S}$ electrode. The kinetic ion-diffusion coefficients of the two electrode materials could be calculated from equation $1[28,29]$ :

$$
D_{M g^{2+}}=\left[\frac{R^{2} T^{2}}{2 A^{2} n^{4} F^{4} C^{2} \sigma^{2}}\right]
$$


Table 1. Comparison of the evaluated electrochemical impedance parameters, $\mathrm{A}_{\mathrm{W}}$ and $\mathrm{D}_{\mathrm{Mg}}^{+2}$ values of $\mathrm{Mg} / \mathrm{V}_{2} \mathrm{O}_{5}$, $\mathrm{Mg} /\left(\mathrm{V}_{2} \mathrm{O}_{5} / \mathrm{S}\right)$.

\begin{tabular}{ccc}
\hline EIS parameters & $\mathrm{V}_{2} \mathrm{O}_{5}$ & $\mathrm{~V}_{2} \mathrm{O}_{5} / \mathrm{S}$ \\
\hline \hline $\mathrm{R}_{\Omega}[\Omega]$ & 23.46 & 23.74 \\
$\mathrm{CPE}-\mathrm{T}$ & 0.00045 & 0.00050 \\
$\mathrm{CPE}-\mathrm{P}$ & $9.05 \times 10^{-5}$ & 0.00011 \\
$\mathrm{R}_{\mathrm{ct}}[\Omega]$ & 146.94 & 169.75 \\
$\mathrm{~W}_{\mathrm{S}}$ & 206.9 & 218.29 \\
$\mathrm{D}_{\mathrm{Mg}}^{+2}\left[\mathrm{~cm}^{2} \cdot \mathrm{s}^{-1}\right]$ & $2.3 \times 10^{-12}$ & $2 \times 10^{-12}$ \\
\hline
\end{tabular}

where $\mathrm{R}=8.314 \mathrm{~J} / \mathrm{mol}, \mathrm{K}$ is the universal gas constant, $\mathrm{T}$ is the absolute temperature, $\mathrm{A}$ is the surface area of the cathode $\left(1.5 \mathrm{~cm}^{2}\right), \mathrm{n}$ is the number of the electrons transferred in the electronic reaction, $\mathrm{F}$ is the Faraday constant $96485 \mathrm{C} \cdot \mathrm{mol}^{-1}, \mathrm{C}$ is the concentration of magnesium ions $\sim 4 \times 10^{-4}$ $\mathrm{mol} \cdot \mathrm{cm}^{3}, \sigma$ is the Warburg factor which is related to $Z_{\mathrm{re}}$ :

$$
Z_{r e}=R_{s}+R_{c t}+\sigma \omega^{-\frac{1}{2}}
$$

where $Z_{\text {re }}$ is the real part of the resistance in the low frequency region, $\omega$ is the corresponding frequency. Fig. 7b shows the plot between $\mathrm{Z}_{\mathrm{re}}$ the reciprocal square root of frequency $\omega^{-1 / 2}$ in the low frequency region. The diffusion coefficients $\mathrm{D}_{M g}^{+2}$ of magnesium ion in different cathodes were calculated by equation 1 and presented in Table 1 . The value of $\mathrm{D}_{\mathrm{Mg}}^{+2}$ is slightly higher in the $\mathrm{V}_{2} \mathrm{O}_{5}$ $\left(2.3 \times 10^{-12} \mathrm{~cm}^{2} \cdot \mathrm{s}^{-1}\right)$ than in the $\mathrm{V}_{2} \mathrm{O}_{5} / \mathrm{S}(2 \times$ $10^{-12} \mathrm{~cm}^{2} \cdot \mathrm{s}^{-1}$ ) electrode, and this can be attributed to that the activation energy $\left(\mathrm{E}_{\mathrm{a}}\right)$ barrier for the migration of interstitial $\mathrm{Mg}^{+2}$ to be overcome is a bit higher in the $\mathrm{V}_{2} \mathrm{O}_{5} / \mathrm{S}$ compared with the pristine $\mathrm{V}_{2} \mathrm{O}_{5}$.

\section{Conclusions}

The as-prepared sheet-like $\mathrm{V}_{2} \mathrm{O}_{5} / \mathrm{S}$ composites prepared by sonochemical method were employed as a cathode in a magnesium battery. This material exhibits a nanorod morphology. The orthorhombic structure of $\mathrm{V}_{2} \mathrm{O}_{5}$ was not affected by modification with sulfur. However, sulfur caused a small expansion of interplanar distances of $\left(\begin{array}{lll}0 & 0 & 1\end{array}\right)$ crystal planes from $4.34 \AA$ to $4.35 \AA$ which may improve
$\mathrm{Mg}^{2+}$ ion diffusion and storage. Generally, modification of $\mathrm{V}_{2} \mathrm{O}_{5}$ with sulfur can improve its electrical and electrochemical performance as magnesium battery cathode. The $\mathrm{V}_{2} \mathrm{O}_{5} / \mathrm{S}$ cathode delivered a high initial capacity $\sim 310 \mathrm{mAh} \cdot \mathrm{g}^{-1}$ enlightening the promising future of high capacity cathode for magnesium ion batteries.

\section{Acknowledgements}

This work is partial financially supported by the Support Development of Scientific Research Center of Benha University (SDSRC) (Grant No. 1076) and the Science Technology Development Fund (Grant No. 12564).

\section{References}

[1] Son S.-B., Gao T., Harvey S.P., Steirer K.X., Stokes A., Norman A., Wang C., Cresce A., XU K., BAN C., Nat. Chem., 1 (2018) 1.

[2] Aurbach D., Lu Z., Schechter A., Gofer Y., Gizbar H., TURgeman R., COHEN Y., Moshkovich M., LeVi E., Nature, 407 (6805) (2000), 724.

[3] Aurbach D., Suresh G.S., Levi E., Mitelman A., Mizrahi O., Chusid O., Brunelli M., Adv. Mater., 19 (23) (2007), 4260.

[4] Xu M., Lei S., Qi J., Dou Q., LiU L., Lu Y., Huang Q., Shi S., Yan X., ACS Nano, 12 (2018), 3733.

[5] Bhandavat R., David L., Singh G., J. Phys. Chem. Lett., 3 (11) (2012), 1523.

[6] Canepa P., Gautam G.S., Hannah D.C., MaLiK R., LiU M., Gallagher K.G., Persson K.A., Ceder G., Chem. Rev., 117 (5) (2017), 4287.

[7] Gershinsky G., Yoo H.D., Gofer Y., AurBACH D., Langmuir, 29 (34) (2013), 10964.

[8] Gregory T.D., Hoffman R.J., Winterton R.C., J. Electrochem. Soc., 137 (3) (1990), 775.

[9] Matsui M., J. Power Sources, 196 (16) (2011), 7048.

[10] Mitelman A., Levi E., Lancry E., Aurbach D., ECS T., 3 (27) (2007), 109.

[11] Novák P., ImHof R., HaAs O., Electrochim. Acta, 45 (1 - 2) (1999), 351. 
[12] Nuli Y., Yang J., Li Y., Wang J., Chem. Commun., 46 (21) (2010), 3794.

[13] Seh Z.W., Sun Y., Zhang Q., Cui Y., Chem. Soc. Rev., 45 (20) (2016), 5605.

[14] Shterenberg I., Salama M., Gofer Y., Levi E., AURBACH D., MRS Bull., 39 (5) (2014), 453.

[15] Song J., Sahadeo E., Noked M., LeE S.B., J. Phys. Chem. Lett., 7 (9) (2016), 1736.

[16] Whittingham M.S., Chem. Rev., 104 (10) (2004), 4271.

[17] Yoo H.D., Shterenberg I., Gofer Y., GershinSKY G., POUR N., AUrBaCH D., Energ. Environ. Sci., 6 (8) (2013), 2265.

[18] Zhang R., Yu X., Nam K.-W., Ling C., Arthur T.S., SONG W., KnAPP A.M., Ehrlich S.N., YANG X.-Q., Matsui M., Electrochem. Commun., 23 (2012), 110.

[19] Sheha E., El-Deftar M., J. Solid State Electr., 22 (9) (2018), 1.

[20] Drosos C., Jia C., Mathew S., Palgrave R.G., Moss B., Kafizas A., Vernardou D., J. Power Sources, 384 (2018), 355.

[21] Londero E., Schröder E., Phys. Rev. B, 82 (5) (2010), 054116
[22] Wang Y., CaO G., Chem. Mater., 18 (12) (2006), 2787.

[23] Tang H., Peng Z., Wu L., Xiong F., Pei C., An Q., MAI L., Electrochem. Energ. Rev., 1 (2) (2018), 169.

[24] Su D., Dou S., Wang G., J. Mater. Chem. A, 2 (29) (2014), 11185.

[25] Jia M.-Y., Xu B., Deng K., He S.-G., Ge M.-F., J. Phys. Chem. A, 118 (37) (2014), 8106.

[26] Zhao-Karger Z., Zhao X., Wang D., DieMANT T., BEHM R.J., FichtNer M., Adv. Energ. Mater., 5 (3) (2015), 1401155.

[27] Vinayan B., ZhaO-Karger Z., Diemant T., CHAKRAVADHANUla V.S.K., SCHWARZBURGER N.I., CAMBAZ M.A., BEHM R.J., KÜBEL C., FichtNer M., Nanoscale, 8 (6) (2016), 3296.

[28] Liu C., Wang X., Deng W., Li C., Chen J., Xue M., Li R., Pan F., Angew. Chem. Int. Edit., 57 (24) (2018), 7046.

[29] Ghorbanzadeh M., Farhadi S., Riahifar R., HADAVI S., New J. Chem., 42 (40) (2018), 1. 